\title{
Tønder Statsseminarium 1937-1943
}

\author{
Af Morten Bredsdorff
}

I Sønderjyske Årbøger 1968 er meddelt en samling dagbogsblade fra Tonder Statsseminarium under den tyske besættelses sidste to år 1943-45. Her følger en kort beretning om seminariets historie 1937-43, bygget på kontorets dagbøger og de officielle indberetninger til Undervisningsministeriet, som den nuværende rektor venligt har stillet til min rădighed.

\section{Tonder før krigen}

Den 22. august 1937 modtog jeg fra Undervisningsministeriet udnævnelse til forstander for Tender Statsseminarium fra 1. september samme år. Med meget kort varsel måtte jeg bryde op fra Silkeborg Seminarium, som dengang blev ledet af forstander, cand. theol. Herluf Jensen, ${ }^{1}$ endnu i delvis samarbejde med den afgående grundlægger af det midtjyske seminarium, den landskendte grundtvigianer P. J. M. Winther. ${ }^{2}$ Jeg var glad ved samarbejdet med et hyggeligt, lidt gammeldags præget lærerkollegium med flere betydelige personligheder foruden den livfulde gamle Winther, der stadig underviste med munterhed og varme. Men jeg befandt mig ikke helt vel i det landskabeligt indelukkede Silkeborg, omgivet af dystre skove og små søer. Jeg har altid været friluftsmand, og sejlture i kano på Gudenåen var min trøst. Men jeg savnede udsynet og friskheden ved min barndoms Roskildefjord og den lette adgang til det sydfynske øhav, som vi havde haft under fem larerår ved Ollerup Højskole. Der havde desuden venskabet med den vidsynede og særprægede, danskargentinske forstander Lars Bækhøj været mig til stor glæde. ${ }^{3}$

Og nu skulle vi til Tønder. Mens jeg glædede mig ved udsigten til en ansvarsfuld stilling $\mathrm{i}$ det åbne vestslesvigske grænseland, var min 


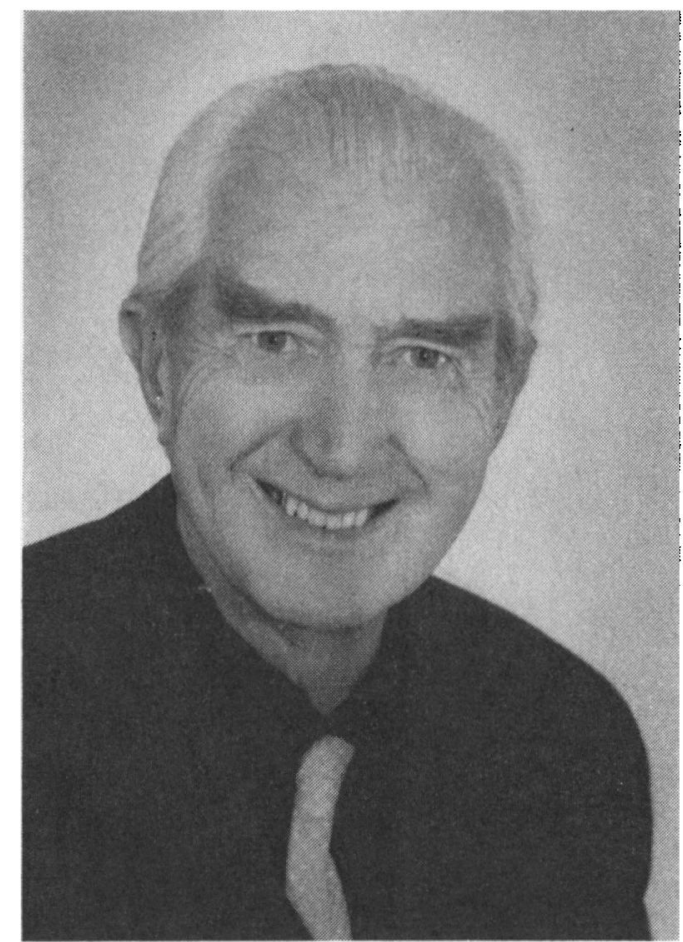

Seminarierektor, mag. art. Morten Bredsdorff, f. 1901.

schweiziskfødte hustru ikke særlig glad og meget bekymret for opgaven som en forstanders kone. Hun følte sig hjemme i det midtjyske bakkeland, vor søn Thomas var kun fire måneder gammel, en flytning forekom hende både ængstende og besværlig. Det var derfor både med bekymring og forventning, vi så hen til den store opgave.

Året før havde jeg talt ved et skolemøde på det gamle seminarium i grænsebyen. Emnet var vekselvirkning mellem dansk og tysk kultur i 1800-tallet, og bagefter havde jeg en god samtale med den gamle forstander pastor Emil Albeck, ${ }^{4}$ der kort efter tog sin afsked. Desuden havde jeg, på opfordring af min gamle lærer Erik Appel, ${ }^{5}$ nu domæneforpagter på Ellehus ved Jejsing, taget initiativet til en indsamling, som skulle støtte rejsningen af et forsamlingshus i nærheden af Ellehus. Det skulle skænkes til »den truede firkant i Slogs herred som en slags håndslag til sønderjyder under den larmende 
nazistiske opmarch i Tyskland og lige syd for grænsen. „Silkeborgsalen, « som huset kom til at hedde, blev da også indviet $\mathrm{i}$ efteråret 1937 og står endnu.

$\mathrm{Da}$ forstanderboligen $\mathrm{i}$ Tønder skulle gennemgå en større istandsættelse, måtte jeg efter et besøg hos undervisningsminister Jørgen Jørgensen ${ }^{6}$ og departementchef A. Barfod ${ }^{7}$ rejse alene til Tønder først i september og begynde arbejdet.

Dengang kendte man ikke de senere indførte højtidelige indsættelser af nye seminarieforstandere ved minister eller statskonsulent. I Tønder blev jeg den 8 . september budt velkommen af den nyudnævnte amtsskolekonsulent for Åbenrå-Sønderborg amt, Hans Novrup. ${ }^{8}$ Selv holdt jeg en kort tale, hvor jeg udtrykte håbet om et godt samarbejde og bistand fra kolleger. Så begyndte undervisningen, jeg overtog straks 12 dansktimer og boede indtil videre på Missionshotellet.

Men selv om jeg meget måtte savne familien og kun hveranden eller tredje søndag kunne nå en hastig rejse til vort hjem Vesterlide i Silkeborg, blev tiden hurtig så fyldt med opgaver, at den fløj. Seminarielærer Claus Eskildsens ${ }^{9}$ velkomst på lærerværelset ved den første frokost var mindre højtidelig end $i$ festsalen forud. Han sagde kort og godt: »Nu har jeg været lærer på Tønder Statsseminarium under fem forstandere, den ene værre end den anden! Nu skal vi se, hvordan denne mand bliver. Velkommen!« Dermed var isen brudt. Under munter latter fra hele lærerkollegiet trykkede Eskildsen og jeg hinanden $\mathrm{i}$ hånden, og jeg blev mødt med venlig åbenhed fra alle sider. Med Eskildsen selv fik jeg under hele min Tøndertid og ikke mindst under besættelsen et fortrinligt samarbejde. Han lærte mig den dybere betydning af det tyske begreb "Dienst «. Med sand kantiansk pligtfølelse over for arbejde og institution var han altid - dag og nat - rede til med råd og gerning at hjælpe den unge forstander, når det gjaldt seminariets vel. Det skulle ske ret of te $\mathrm{i}$ de kommende år.

Seminariets lærerkollegium var - målt med nutidens stok - kun lille. Magister Aage Rahr ${ }^{10}$ kendt jeg i forvejen, de øvrige lærte jeg snart at kende. Et karakteristisk træk var her det fornøjelige fællesskab mellem seminariets og øvelsesskolens lærere og lærerinder. Et stort lærerværelse samlede dagligt næsten alle $\mathrm{i}$ pauserne og det store spisefrikvarter. Her præsiderede overlærer Thomas Roust, ${ }^{11}$ en stor rolig vestjyde, for den ene ende af det lange bord. Han ankom gerne 
tungt rustet til vore formiddagssamtaler, kan kendte jo det hele langt bedre end jeg. I 1941 blev han udnævnt til amtsskolekonsulent for Haderslev amt og afløstes som overlærer af Erling Brahm. ${ }^{\mathbf{1 2}}$

Endnu et par medhjælpere må nævnes. Den stoute pedel Johs. Bonde, ${ }^{13}$ en forhenværende Haderslevskipper, som hver morgen stod foran hovedindgangen og hilste forstander og lærere med sin mørkeblå sømandskasket. Han kendte næsten alle skrivelser på min forgangers kontor, hjalp mig fortrinligt til rette med mange løbende sager og var altid tjenstvilligheden selv overfor " $\mathfrak{X}$ forstander “. Måske nu og da lidt for meget af det gode. Han var en støt hjxlper de første år. Men da lærerrådet ved hans afgang på det bestemteste frarådede mig at opfylde hans ønske og $\mathrm{i}$ hans sted ansætte hans søn, der hverken havde uddannelse eller erfaring, vendte venskabet sig til bitter uvilje. I Bondes sted fandt jeg med Eskildsens hjxlp en xldre snedker fra byen Rasmus Frandsen. ${ }^{14}$ Han blev ikke blot en enestående dygtig pedel, der sparede staten mange penge ved sine egenhændige reparationer af større og mindre skader, men også mine børns trofaste og muntre ven, en mand jeg aldrig glemmer.

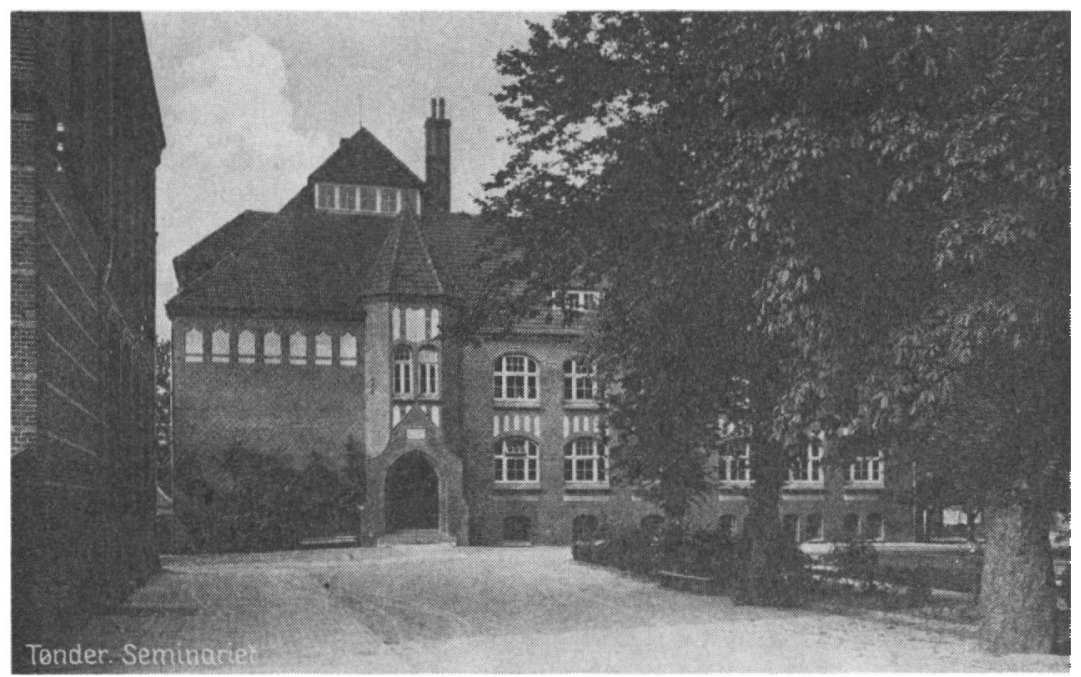

Tønder Statsseminarium i mellemkrigstiden. (Historiske Samlinger for Sønderjylland) 
Den anden var gymnasielærer Peter Atke, som fra Albecks tid ordnede seminariets ret indviklede regnskab. ${ }^{15} \mathrm{Han}$ var en solid og fornøjelig støtte, hvis sjællandske tonefald lød hjemligt i mine øren. Ved sin alt for tidlige død i 1942 aflostes han af seminarielærer Jørgen Utoft, der blev en ikke mindre fortrinlig regnskabsfører og medhjxlper. ${ }^{16}$

Sidst $\mathrm{i}$ oktober ankom min kone og vore to børn fra Silkeborg til den nu nogenlunde istandsatte, blot alt for store og gammeldags embedsbolig, der jo stammer fra 1850'erne. Med sine 30 rum, de 8 dog i kælderen, forskrækkede den straks min kone. Værre var og blev boligens solfattige beliggenhed med det nu nedrevne store bryggeri lige overfor på Østergade. I det barske vestslesvigske klima skulle det vise sig skæbnesvangert, ikke mindst for hendes og Thomas' helbred. Lykkeligvis fik vi det år en ret mild og varm november, og jeg kan endnu høre den hyggelige rappen af xnderne på Vidåen, når man vågnede om morgenen. Men vintrene var hærget af of te langvarige sygdomme for min kone og børnene, så længe vi var i Tønder.

Sammen oplevede vi et glimt af det gamle Tonder, da et hjemmetysk ægtepar fejrede guldbryllup i landauer gennem Østergade, hvor alle, danske og tyske borgere, hyldede dem med lys $\mathrm{i}$ vinduerne. Vi var med til aftenfesten $\mathrm{i}$ "Tonhalle «, hvor lokale kræfter opførte den muntre komedie "Der verschriebene Vetter " med djærve repliker på tysk, frisisk, sønderjysk og plattysk, en sidste efterklang af den gamle dansk-tyske helstat.

De første år i Tønder var præget af travlhed og vækst. Det i 1930'erne noget stagnerende seminarium i landets sydvestre hjørne fik inden længe så mange ansøgninger om optagelse, at spørgsmål om udvidelse og indretning af dobbeltklasser snart måtte rejses. Dette skyldtes i første række den stigende spænding syd for grænsen, hvor den propagandaberuste nationalsocialisme $i$ disse år voksede fra måned til måned, og som allerede havde nogle af sine stærke forposter i Holsten og Sydslesvig. Herfra lød gentagne krav om grænseflytning. En fanatisk pastor Peperkorn ${ }^{17}$ råbte op om »den blødende grænse « ved Kruså. Han og andre forlangte den flyttet »bis an die Königsau “. Det trak op til storm. Derfor er det et kønt træk i dansk ungdoms holdning $\mathrm{i}$ disse år, at den $\mathrm{i}$ stort tal sluttede op om Det unge Grænseværn og dets møder på Dybbøl. Et stigende antal unge mænd og kvinder besluttede nu, of te vel tilskyndet af slægt og 
venner, at lægge deres læreruddannelse i den mest udsatte by i landet, den gamle gransestad i marsken.

Hertil kom, at vi ufortrødent måtte i gang med de af min forgxnger indledede forberedelser til Tonder Statsseminariums 150 års jubilæum, som skulle fejres den 24. september 1938. Man mærkede, at det var en begivenhed, som byen og Vesteregnen så hen til med levende interesse. Den skulle slå fast, at de danske var her endnu og agtede at blive. En festkomité, bestående af Claus Eskildsen, seminarieelev Tage Dam ${ }^{18}$ og forstanderen lagde planer, forberedte festskrift og droftede med undervisningsministeriet listen over indbydelser. Kronprins Frederik ${ }^{19}$ og kronprinsesse Ingrid, ${ }^{20}$ der på dette tidspunkt opholdt sig på Gråsten slot, havde lovet at deltage. Undervisningsminister Jørgen Jørgensen, departementschef Barfod og en række embedsmænd havde ligeledes givet tilsagn. De sønderjyske rigsdagsmænd med H. Jefsen Christensen ${ }^{21}$ og I. P. Nielsen ${ }^{22}$ var selvskrevne gxster. Amtmand grev O. D. Schack skulle holde festtalen. ${ }^{23}$

\section{Jubilaum under stormvarsel}

Inden festdagen oprandt, indtraf imidlertid en rxkke begivenheder, verdenshistoriske og provinsielle, som nær havde kuldkastet alle planer. I slutningen af somren 1938 nærmede den storpolitiske krise i Europa sig sit højdepunkt. Den 15. marts var Hitler rykket ind i Czekoslovakiet og havde ladet sig hylde i Prag, mens vestmagterne afmægtige så til. Somren var svanger med krigstrusler. Churchill124 tordnede mod eftergivenhedspolitikken, og Anthony $\mathrm{Eden}^{25}$ trådte tilbage. Den 15. september fløj den britiske premierminister Neville Chamberlain ${ }^{26}$ til Berchtesgaden for at forhandle med Hitler. Han vendte skuffet tilbage, rygterne tog til, og uroen voksede overalt. I Tonder overvejede man nu helt at opgive jubilæet den 24. september. To dage før, den 22., fløj Chamberlain igen til møde med Hitler, denne gang $i$ Godesberg ved Rhinen. Alligevel støttede både ministerium og amtmand os $\mathrm{i}$ ønsket om at gennemføre festen. Og mens de tyske krigstrusler voksede fra time til time, fejrede det gamle danske seminarium, $i$ en atmosfære af uforglemmelig spænding - krig eller fred de nærmeste dogn - den planlagte mindefest for landets ældste lærerskole.

Kort forud havde en lille lokal affære som et fugleskrig under 
tordenvejr flettet sig ind $\mathrm{i}$ det store drama. I foråret havde man $\mathrm{i}$ det tyske mindretals dagblad Nordschleswigsche Zeitung kunnet læse, at den tyske lærerforening i Nordslesvig sammen med lærerforeninger i Slesvig-Holsten havde besluttet at fejre mindet om det gamle seminariums 150-årige beståen ved en festlig sammenkomst i Tønder den 10. september. Det blev endvidere oplyst, at skolemyndighederne i Slesvig agtede at give tyske Tønder-dimittender fri den dag, for at de kunne deltage i festen på restaurant Skyttegården i Tønder.

Seminariet havde ikke modtaget nogen indbydelse eller direkte meddelelse om denne tyske mindefest. Men efter samråd med grev Schack og amtsskolekonsulent Nicolai Svendsen ${ }^{27}$ besluttede jeg på seminariets vegne at sende den tyske lærerforenings formand, skolekonsulent Elholm, ${ }^{28}$ Tinglev, en indbydelse til at besoge seminariet med festens deltagere. Han indfandt sig personlig på mit kontor, takkede for indbydelsen, som man gerne ville modtage og tilføjede, at foreningerne gerne ville nedlægge kranse ved seminariets mindestene for stifteren Balthasar Petersen ${ }^{29}$ og for de faldne fra Verdenskrigen. Han spurgte derefter, om det kunne tillades de tyske gxster sydfra at hilse monumentet med »den tyske hilsen «. Da vi for enhver pris ville undgå et gjaldende Heil Hitler! i seminariegården, svarede jeg, at det kunne tillades, når det skete »uden nævnelse af et fremmed statsoverhovedes navn«. Han lovede, at det skulle ske $i$ tavshed, og at man hverken agtede at synge eller på anden vis demonstrere.

Lordag den 10. september fyldtes gården over middag af ca. 300 mørktklædte lærere, de fleste sydfra. De stillede op i kreds om obelisken, mens Nicolai Svendsen, hvem jeg havde bedt komme til stede, og jeg stilfærdigt gik omkring og hilste på enkelte. Formanden talte kort om det gamle tyske seminarium, på tysk naturligvis, og en stor krans blev nedlagt. Et øjebliks anspæendt pause indtrådte. Kun enkelte arme blev løftet, og ingen sagde noget. Kort efter tog forsamlingen afsked og begav sig til den planlagte "Essen " hvor der efter sigende ikke blev sparet på festtaler og hyldest til den tyske "Fører «. Men det kom ikke seminariet ved.

Da seminariets egen festdag oprandt, var vejret skønt og mildt, en af disse varme, dejlige sensommerdage, som har en egen glans i marsklandet. Det varme vejr var åbenbart årsag til, at den store tyske krans nu to uger senere ved foden af "Balthasars obelisk « var falmet og så trist $u d . ~ O g$ da vi vidste, at Undervisningsministeriet agtede at 


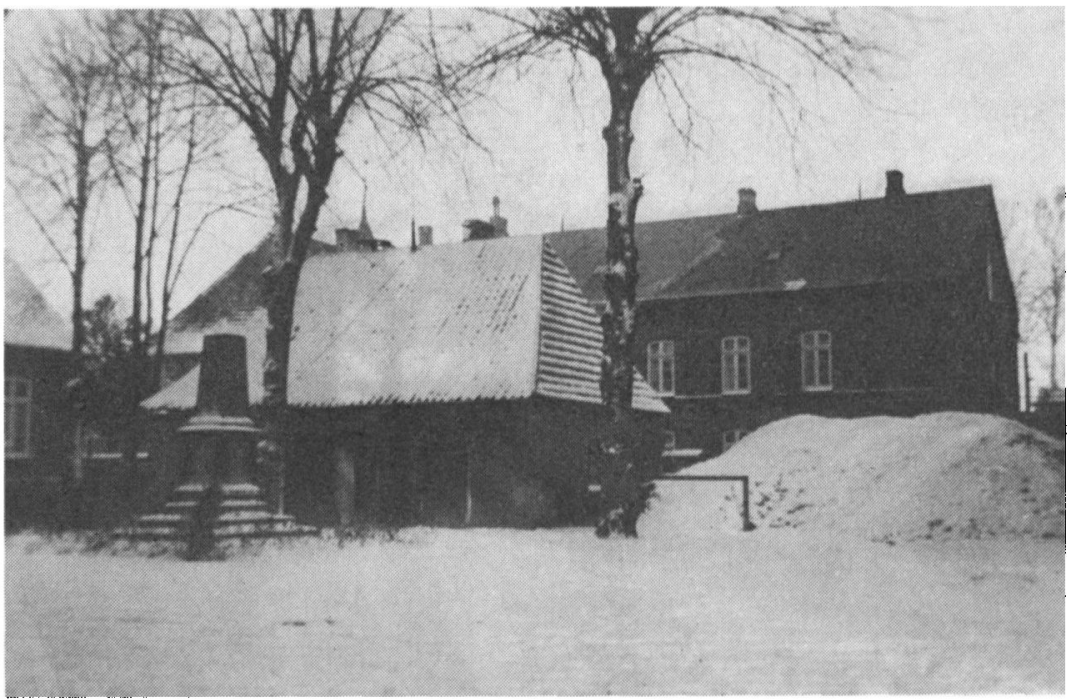

Den gamle staldbygning $i$ statsseminariets gård, nedrevet 1940. I forgrunden mindestenen for Balthasar Petersen.

nedlægge en krans samme sted, gav jeg intetanende pedellen besked om at fjerne den visne, tyske krans. Deraf fulgte et ret ubehageligt efterspil. Men ferst vor egen fest.

Her dannede den gamle festsal rammen om en stor, festklædt forsamling med kronprinsparret på første række. Undervisningsministeriets gave, et stort billede af Joakim Skovgaard, Jomfru i Fugleham, var ophængt på sydvæggen. ${ }^{30}$ Undervisningsminister Jørgen Jørgensen lykønskede det gamle seminarium i varme ord. Så stod grev O. D. Schack på talerstolen. Åndfuldt skildrede han den gamle lærerskoles skiftende faser i grænselandets spændingsfyldte luft.

"Vi ved ", sagde han, "at der allerede én gang for her på Vesteregnen er opstået en bevægelse, der havde en vis tilknytning til seminariet, og der onskede at udligne de nationale spændinger ved et samliv i frihed og gensidig forståelse. Dengang fik bevægelsen ikke tid til at sxtte sig igennem, og selv om vi håber, at nogle af de tanker senere, efter 1920, er fort ud i livet, så gælder det for os nu som dengang at være lydhøre over for de krav, der stadig påny stilles os, fordi vi lever på Sønderjyllands jord, og som visselig ikke bliver 
mindre nu $\mathrm{i}$ en jerntid, hvor spændingen mellem landene øges, og jorden dirrer sagte af hæres opmarch.

Også den enkelte har her et personligt ansvar, ikke kun over for sin egen nationalitet, hvis livsvilje skal bæres frem med stærk og varm inderlighed, men også et ansvar over for den anden nationalitet, som vi skal leve i umiddelbar berøring med.

At blive kloge på denne måde og at forene den dobbelte pligt mod sit eget folk og mod sin næste $i$ en højere harmoni, det er grænsesindets visdom og det, vi skal lære vor ungdom, der bærer landsdelens fremtidsskæbne.

$\mathrm{Da}$ lærernes livsopfattelse, således som den kommer til at præge deres undervisning i skolen, får en så stor indflydelse på den opvoksende slægt, er det af stor betydning, at denne anstalt stadig føler sig som et grænseseminarium $\mathrm{i}$ ordets bedste betydning.

Det er en ære for denne skole, at den kan se tilbage på en 150 år gammel tradition som grænseseminarium og en lykke, at den, vågen og virkeglad, i nutiden har en så alvorlig og skøn opgave foran sig som ingen anden læreruddannelsesanstalt $i$ dette land «.

Jeg sluttede med en kort historisk oversigt over de 150 forløbne år og fremhævede 1850 ernes djærve danske forstander A. Kühnel ${ }^{31}$ med de skarpe Carl Plougske træk, og Cornelius Appel, ${ }^{32}$ en af førerne for den af grev Schack nævnte forsonlige »Klosterpolitik " omkring 1860 , og lovede, at vi uanset, hvad der måtte ske, ville stræbe at arbejde $\mathrm{i}$ den ånd, som grænselandets amtmand så smukt og sandt havde skildret.

Ved en frokost i gymnastiksalen blev der holdt flere gode taler, bl. a. af landstingsmand Jefsen Christensen, borgmester Jepsen ${ }^{33}$ og andre. Mødet i festsalen blev transmitteret af statsradiofonien, noget dengang ret nyt. Samtidig modtog ministeren og hans embedsmænd regelmæssigt telefonisk nyt fra udenrigsministeriet om den store krises udvikling. Vi fik at vide, at Chamberlain endnu forhandlede med Hitler, men udgangen var stadig aldeles usikker.

Mange tidligere Tønderelever fra hele landet var mødt frem. Derfor måtte vi henlægge aftenfesten til kasernens store sal, hvor Claus Eskildsen holdt en djerv og munter tale om tysk og dansk i Slesvig. Her talte virkelig "den sidste slesviger", som vi ofte kaldte ham. Og så blev der spillet op til dans i vor egen gamle festsal, noget helt nyt på dette sted. Min forgænger havde ikke tilladt dans i semina- 
riets lokaler. I dette øjeblik fik vi fra det lokale danske dagblads kontor den seneste meddelelse fra London: Chamberlain var for et par timer siden steget ud af flyvemaskinen, havde viftet med et stykke papir og råbt. »Dette betyder fred $\mathrm{i}$ vor tid! « England genlød af taknemlige jubelråb. Om disse ord skrev min studenterkammerat Peter P. Rohde, der opholdt sig i London: "Et folk af kujoner har med instinktiv sikkerhed fundet sin helt $i$ en forræder! « Ord, som han senere måtte "xde $\mathrm{i}$ sig", som han selv sagde, men som udtrykte manges holdning dengang. ${ }^{34}$

Vi følte den aften en umådelig lettelse efter ugens trættende spænding. Enkelte af os anede vel - jeg mindes en samtale herom med en kollega - at England på det tidspunkt var så dårlig forberedt på $\mathrm{krig}$, at en statsleder nødvendigvis måtte tilvejebringe en udsættelse, om han ikke kunne opnå andet.

Dagen efter foretog pastor Kaj Munk ${ }^{35}$ en mindestens afsløring $\mathrm{i}$ Abild. Men om mandagen indeholdt Nordschleswigsche Zeitung en skarp hilsen til statsseminariet og dets forstander. Med dyb forargelse meddeltes det, at man havde begået »gravskændsel « ved at fjerne den slesvigholstenske lærerforenings krans fra provst Petersens mindesten. Dette var en grov fornærmelse mod den tyske befolkning og måtte medføre alvorlig klage til ministeren. Samtidig oplystes, at seminariets nye ledelse havde gjort sig skyldig $i$ en anden grov udfordring, idet en »jødisk rabbiner « nylig havde holdt foredrag for seminariets elever og det endda $i$ undervisningstiden! Den slags "Unfug " skulle man ikke længere finde sig $i$.

"Rabbineren " var en tåbelig misforståelse, der hang sammen med nazismens uhyggelige antisemitisme. Jeg havde bedt min gode ven, Jan Ballin, ${ }^{36}$ på den tid katolsk præst $\mathrm{i}$ Esbjerg, fortælle eleverne om digteren Johannes Jørgensen, et led i nogle frie litterære dansktimer, jeg havde indført, og hvor Kaj Munk kort efter skulle føre ordet. Det blev en oplxsning og gennemgang af skuespillet Cant. Men beskyldningen for gravskændsel var ubehagelig $\mathrm{i}$ den betændte atmosfære. Jeg drøftede sagen med Claus Eskildsen. Vi var enige om, at bladets kilde måtte være to elever $\mathrm{i}$ III klasse, der begge tilhørte mindretallet. Jeg kaldte dem ned på mit kontor, fortalte dem, at jeg var klar over, at de havde forsynet bladet med disse fordrejede oplysninger. Hvad kransen angik, havde de selv kunnet se, at den efter 2 uger var vissen og grim og kun blev fjernet for at give plads for 


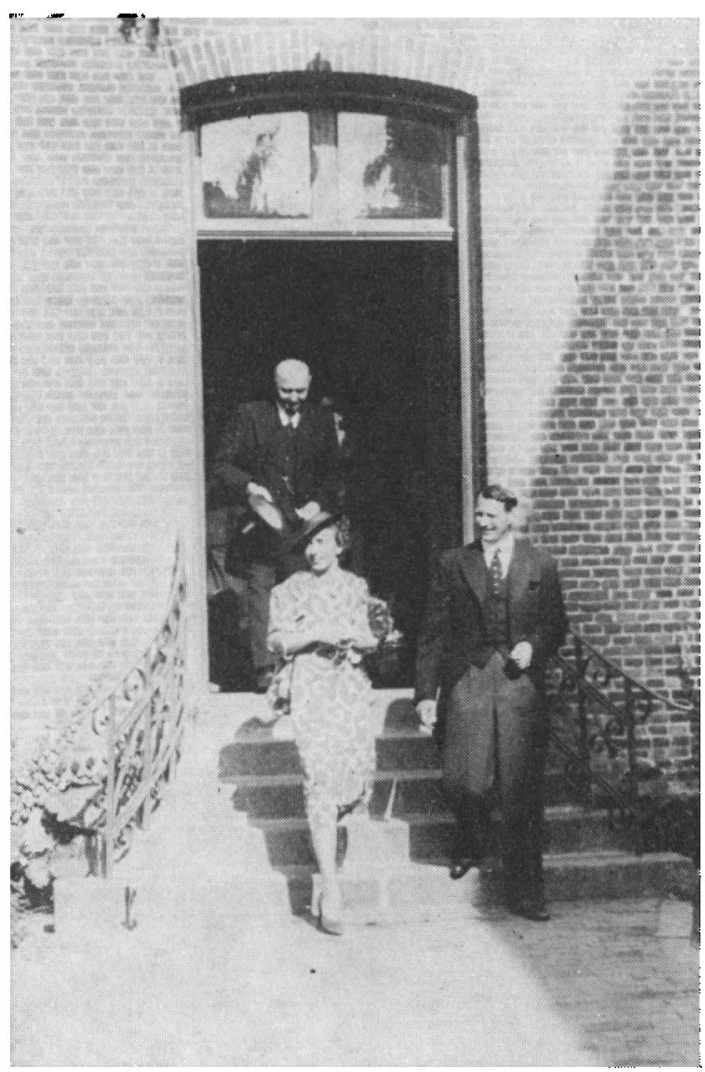

Kronprins Frederik og kronprinsesse Ingrid ved forstanderboligen ved seminariet den 24. sept. 1938. Bag dem undervisningsminister Jorgen Jargensen.

undervisningsministeriets friske krans. De to elever nægtede ikke og med besked om, at de ville blive bortvist, dersom bladet ikke indstillede denne kampagne, blev de sendt afsted til det tyske blads redaktion. Efter nogle brummende vredesudbrud ebbede sagen ud $i$ de følgende dage, og glad var jeg.

\section{Krig eller fred?}

Den 29. september fløj Chamberlain igen til Tyskland. Denne gang for $\mathrm{i}$ München sammen med den italienske diktator Mussolini og den franske statsminister Daladier at underskrive den for vestmagterne 
så ydmygende "Appeasement-Treaty «, der siden blev et slags fællesord for uværdige og falske forlig.

Men krigsudbruddet var udsat, der faldt en vis ro over grænselander, vi kunne i nogenlunde ro arbejde videre med vore elever, hvis tal nu var $\mathrm{i}$ god vækst. I foråret 1939 var der $\mathrm{i}$ april tilmeldt så mange ansøgere til den forestående optagelsesprøve, at jeg med lærerrådets fulde tilslutning anmodede Undervisningsministeriet om lov til at oprette dobbeltklasse fra august. Det var dengang en sag, som krævede tilladelse fra vor øverste myndighed. Man frygtede, at overfyldning af seminariet skulle svække uddannelsens kvalitet.

Der var nu en grund mere til betænkelighed. Den var så tungtvejende, at departementschef Barfod personlig anmeldte sit besøg i Tønder for at drøfte sagen. Amtmand grev Schack indbød derfor ham, amtsskolekonsulent Svendsen, skolekonsulent Elholm og mig til en frokost på Schackenborg. Her drøftede man ret indgående, hvorvidt det måtte anses som forsvarligt under de truende politiske forhold at tillade seminariet i stedet for de sædvanlige 25-30 nye elever at optage 60 på en gang! Grev Schack henstillede indtrængende til Barfod at sige ja, »også for grænselandets skyld“, og med et venligt nik fra den »romerske senator " blev tilladelsen givet. Frokosten fandt sted i maj kort efter, at Hitler havde overskredet grænsen til Böhmen og Mähren og dermed brudt Münchenaftalen. Det var vel dette, der gav Elholm anledning til at ytre sig ret uforbeholdent om Tysklands vældige styrke og de følger for Europa, man nu måtte vente. Vi andre lyttede, ilde berørt, indtil vor kloge amtmand sluttede samtalen med nogle klassiske bemærkninger om det græske begreb whybris«, det overmod, som kan blinde menneskene under medgang; men som guderne altid straffer tilsidst. Elholm var tavs, da vi skiltes $\mathrm{i}$ slottets forhal.

Den 7. april fulgte Mussolini Hitlers kurs og besatte det lille Albanien. Og selv om statsminister Th. Stauning ${ }^{36}$ over radioen udtalte, at "Albanien ligger så langt borte «, følte de fleste, i hvert fald i grænselandet, at det store gennembrud nærmede sig. Eskildsen citerede Bismarcks ${ }^{37}$ ord: Den, der ejer Böhmen, har magten over Europa! Og sammen mindedes vi vort besøg i Göteborg i oktober 1937, hvor vi med seminariets to xldste klasser havde været foreningen Nordens gæster. Under et samvær med Handels- och Sjöfartstidningens temperamentfulde redaktør Torgny Segerstedt $t^{38}$ havde han $i$ 
skarpe ord kritiseret Staunings tale i Lund om Danmark, der ikke ville være »Nordens lænkehund «. »Ser $\mathrm{Ni}$ då inte, att Hitler vil en enda sak, storkrig? Och den kommer snarligen! « Så frit talte man ikke i Danmark.

Sommeren gled hen i ængstende uro. Den 1. september overfaldt Tyskland Polen. Anden Verdenskrig var brudt ud. Vi nåede hjem ud på aftenen med min gamle schweiziske svigermoder, hvem vi ville have glædet med en udflugt til Als. Med den tordensvangre luft lammede al glæde, og få dage efter fulgte min kone sin moder til Hamborg, hvorfra hun slap hjem til St. Gallen. Gribende beskrev hun de tavse medrejsende i toget fra Flensborg, det dødsstille Hamborg med de vældige balloner, der svævede over det som værn mod luftangreb.

Så fulgte den lange vinter 1939/40, den tavse krig, hvor begge krigsførende parters ungdom som gengangere fra Første Verdenskrig lå i skyttegrave overfor hinanden, uden at skyde, uden at kxmpe. Det var rygternes vinter. Hver gang en tjenesterejse forte én til $\mathrm{K} ø-$ benhavn, blev man spurgt ud om stemningen i grænselandet. Ved hjemkomsten ville alle høre nyt fra hovedstaden. Men de reelle nyheder var ikke meget forskellige.

I november bad Statsradiofonien mig om at holde et foredrag om folkestyret og folkeskolen. "Mange higer nu efter en ny oplevelse af den humanitet, den menneskelighed, som synes at forsvinde af den hårde og kolde verden, et hjemsted $\mathrm{i}$ det danske, folkelige fællesskab, uden hvilket vi svæver frit i den tomme luft, en fast tro, om vi ellers ejer den, på den Herre som er livets ophav og mål. - - - Det er vistnok på tide, at den offentlige skoles ængstelse for personlige overbevisninger og dens iver efter at udviske anskuelserne bag neutrale fagrækker hører op. De åndelige kræfters frihed er selve livsnerven $\mathrm{i}$ demokratiet. Åndelig og moralsk neutralitet er kun et fint ord for den ligegyldighed, der får grunden til at skride under folkestyrets hus. Om skolens veje fremad skal gå over friere, mere personlighedsprægede skoleformer inden for den offentlige skole, altså skoler $\mathrm{i}$ lighed med C. N. Starckes Danske Skole, Gregersens Skole og visse friskoler, hvis ledere ikke først og fremmest er administratorer, og hvis lærere ikke blot er ansatte, men også ved åndeligt fællesskab knyttet til den skole, hvis særprægede fysiognomi de tilsammen skaber, vil tiden vise. 
Men skulle det ske, som før $\mathrm{i}$ onde og fattige tider, at der i det brede danske folk igen vågner så megen tillid til egne evner og kræfter, at ikke hveranden dreng og pige skal presses igennem eksamensskolernes nåleøje, og så megen tillid til dets egen åndelige arv, folkestyret og folkefriheden, at man igen får lyst til at besinde sig på disse ting og kæmpe for dem, inden det er for sent, så står også folkeskolens lærere parat til at tage deres part af folkestyrets selvforsvar, eller dets kamp for livet«. (Af radioforedrag 17/11 1939).

Kort efter nytår 1940 kom jeg en aften hjem til en by $i$ oprør. Man fortalte, at alt militær $\mathrm{i}$ byen var $\mathrm{i}$ beredskab, kasernen var lukket, officiantfamilierne stærkt foruroligede.

Var den af det tyske mindretal så heftigt ønskede besæuttelse nu på vej? Sent på efteråret havde elever fra en holstensk "Fahnenjunkerschule « opholdt sig i Tønder nogle dage, og de hagekorsuniformerede ynglinge optrådte særdeles udfordrende. $\mathrm{Da}$ et dansk teaterselskab en aften opførte Kaj Munks drama "Han sidder ved smeltediglen «, var de unge nazister posteret ved teatrets indgang og kom med truende tilråb. $\mathrm{Nu}$ voksede uroen igen.

Den 27. marts 1940 skulle jeg tale ved et skolemøde i Nykøbing F. Vinteren var lang og kold det år, Storebælt endnu delvis islagt. Af mange grunde var jeg alt andet end glad, da jeg en tidlig morgen skulle afsted. Isskodser buldrede mod færgens stævn og sider, østenvinden bed $\mathrm{i}$ ørerne, og der var mange rejsende. I restaurationen studsede jeg over de mange civile tyskere ved bordene, jeg selv fik en på hver side. De var yderst høflige, men hvad skulle de her? Med ubehag forlod jeg færgen, fandt $i$ hast en taxa, der kunne køre mig til Falster, da jeg ikke på anden vis kunne nå frem i tide. Mit næste møde - som ny mand i Sønderjylland deltog jeg de første år i ret mange møder - skulle finde sted på Rinkenæshus ved Flensborg Fjord tirsdag den 9. april. Det blev aflyst.

Kom overfaldet den 9. april bag på os $\mathrm{i}$ Tønder?

Både ja og nej. Vi havde $i$ tre-fire måneder hørt så mange rygter om trusler mod regeringen $i$ Kobenhavn, om flådestyrker $i$ de tyske Østersøhavne, om troppesamlinger i Holsten og Sydslesvig, at de fleste vist hverken vidste ud eller ind. Men jeg erindrer klart, at jeg en af de første dage $i$ april, da foråret endelig syntes på vej, cyklede ud til toldstedet ved Sxd for at tale med min gode bekendt toldkontrolløren dernede. Han havde hørt alle rygterne om tropper $\mathrm{i}$ 


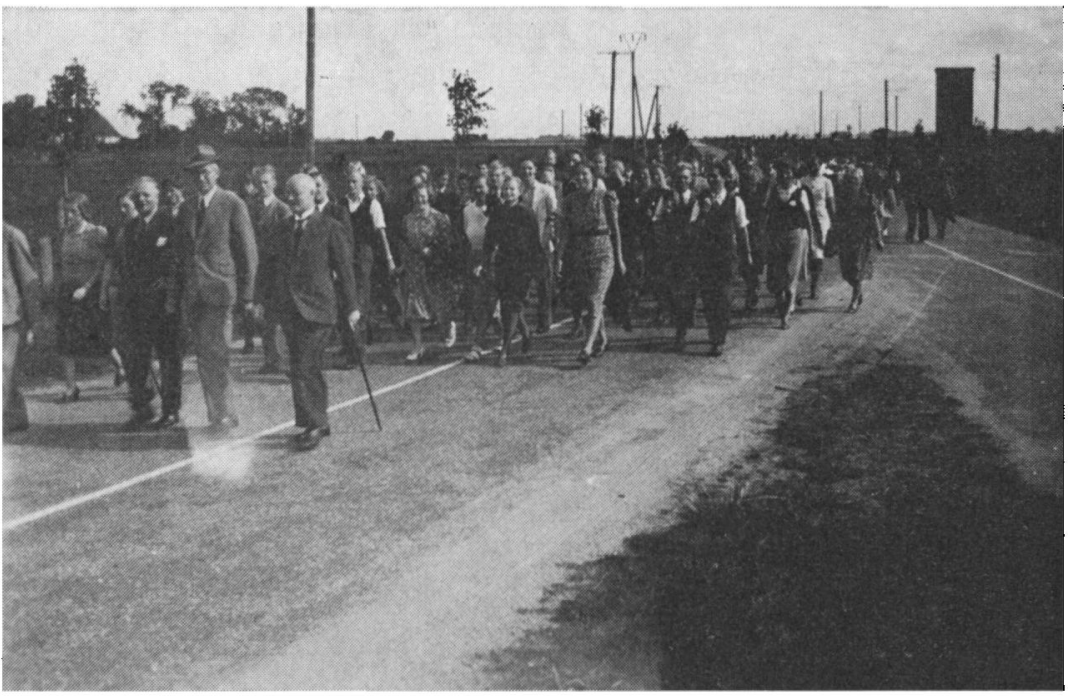

Statsseminariets elever på forårsvandring til Gallebus maj 1938. I spidsen magister Rahr, forstander Bredsdorff og Claus Eskildsen.

skovene uden for Flensborg; men selv havde han i den flade egn intet usædvanligt kunnet se. Vi skiltes med håb om, at faren drev over som så ofte før.

\section{Besattelsen}

Den 9. april vågnede jeg meget tidligt, $i$ halvsøvne havde jeg en fornemmelse af, at der måtte være kommet kulvogne ind $i$ seminariets gård, en jævn buldren som af kul på en slidsk fyldte sovekamret. Pludselig kom vor sønderjyske unge pige skrigende ind ad døren i det bare nattøj: "Tyskerne kommer! Tyskerne kommer!« skreg hun grxdende. Vi for ud af sengene over til værelset, der vendte ud mod Østergade. Det var som en strømmende, grønlig flod, der fyldte gaden fra mur til mur og væltede frem mod Ribelandevej! Gaden var fyldt af marcherende tropper, som sang og skrålede op mod vinduerne. Langs vort fortov enkelte sort uniformerede soldater med opadvendte bøssepiber. Over os de sorte flyvemaskiner, der larmede som kul $i$ en kælderhals. Jeg sprang $i$ tøjet, ned til seminariets låge 
ud mod gaden, hvor pedellens medhjælper Friederich, en godmodig tysker fra Sachsen, som var blevet hængende siden Genforeningen, stod med oprakt arm og hilste de tyske tropper. Jeg bad ham skyndsomst forføje sig ned i fyringskælderen, hvad han skikkelig efterkom, og der blev han resten af dagen.

Om de nærmest følgende begivenheder beretter den umiddelbart . derefter indsendte indberetning:

Tønder Statsseminarium, den 11. april 1940. Til Undervisningsministeriet, 1. dept., København.

Jeg finder det rigtigst at indberette en mindre episode, som fandt sted på seminariets grund tirsdag den 9. d.m. Under de tyske troppers gennemmarch ad Østergade forbi Statsseminariet, der med afbrydelser varede fra tirsdag morgen ca. kl. 5 til onsdag morgen den 10. d.m. ca. kl. 4, og som i sig selv ikke forulempede seminariet, trængte nogle nazistiske tønderborgere $\mathrm{kl} .8,45$ ind på seminariets grund og begyndte at hejse et hagekorsflag på seminariets flagstang ud mod Østergade. Pedellen tilkaldte straks forstanderen, og inden flaget endnu var nået til tops, spurgte jeg anføreren om hans beføjelse til at trænge ind på seminariets grund og opføre sig ulovligt. Han svarede på dansk, at han handlede efter ordre fra »den tyske kommandør «. Da jeg udbad mig en skriftlig tilkendegivelse af dette, blev der svaret med en grovhed, og da jeg protesterede, henviste han til "politimesteren «, som havde givet tilladelse. Flaget blev derpå hængende, mens jeg satte mig $\mathrm{i}$ telefonisk forbindelse med politimester Martensen-Larsen, ${ }^{39}$ der benægtede at have givet nogen sådan tilladelse og henstillede, at vi nedtog flaget og afleverede det til de pågældende herrer. Dette skete på sømmelig og tilbørlig vis, idet det fremmede flag blev sammenlagt af pedellen og en seminarieelev. 10-15 minutter senere, kl. ca. 9,15 var flaget på ny hejst af de samme herrer, forstærket med flere andre i lignende privatuniformeret antræk, og nu posteredes der vagt ved flagstangen. Seminariet trådte på ny i telefonisk forbindelse med politimesteren, der nu henstillede, at vi fra seminariets side lod flaget hænge, indtil spørgsmålet om politimesterens myndighed og flagning var klaret, hvilket formentlig hurtigt ville ske.

Kl. 11,30 samme formiddag indfandt politimesteren sig, og det fremmede flag blev nedtaget og afleveret til de folk, der holdt vagt, 
hvorefter disse forsvandt. Dermed var sagen bragt til afslutning for seminariets vedkommende.

I øvrigt har såvel seminariet som øvelsesskolen trods larm fra flyvemaskiner og motoriserede tropper gennemført undervisningen planmæssigt uden nogen art af afbrydelser.

I xrbødighed

Morten Bredsdorff.

Da seminarieeleverne i frikvarteret efter denne begivenhed kom ud, var der stor jubel omkring den "rensede flagstang «. "Det var sandelig godt gjort «, udbrød vor 3-årige søn, der med sin moder stod på forstanderboligens trappe og să det hele.

Allerede ved 7-tiden var adskillige af seminariets lærere nået frem til vor dagligstue, enkelte fjernereboende kunne overhovedet ikke komme over gaden. Ved et hastigt lærermøde blev det besluttet såvidt muligt at gennemføre seminariets undervisning, skønt det var klart, at mange elever ikke ville kunne nå frem på grund af spærringer. Knap halvdelen af øvelsesskolens børn indfandt sig den dag. De allerfleste blev naturligvis holdt hjemme af forældrene. Lærere og seminarieelever begav sig op i festsalen. Med få ord søgte jeg at forklare, hvad der efter al sandsynlighed var under udvikling. Alt tydede på, at dette ikke blot var en besættelse af Sønderjylland op til Kongeåen, men angik hele landet. „Gud ske lov for det! «, udbrød lærerinde Inger Enemark af sit varme hjerte. »Så gælder det hele Danmark og ikke alene os sønderjyder! « Et vistnok rammende og umiddelbart udtryk for mange sønderjyders følelse i den stund. Så sang vi Alt står i Guds Faderhånd. Flere elever var så bevægede, at de græd. Meget kom der næppe ud af den dags undervisning, flyvere drønede over vore tage, "Oprop « flød på plænerne, tropperne hujede og sang på gaden. Indtil solopgang næste morgen fortsatte denne invasion. Så var Danmark besat.

Tre dage senere, fredag 12. april, lykkedes det første gang at opnå telefonisk forbindelse med Undervisningsministeriet. $\gg \mathrm{Hvad}$, er De i Tønder! « råbte statskonsulent Kaalund-Jørgensen, ${ }^{40} \mathrm{da}$ jeg meldte mig. »Her hedder det, at Tønder er bombet og hele seminariet flygtet! Dermed begyndte den efterretningernes solformørkelse, som skulle vare fem lange år og fremkalde utallige oplysninger af lignende troværdighed. 
Den 20. maj ankom en feldwebel og forlangte kvarter til 200 mand, formodentlig på vej tilbage fra Norge til det nu besatte Frankrig. De krævede klasseværelser, "skriverstue " m.m. samt anbringelse af nogle ammunitionskasser $i$ kxlderen. Pedel Frandsen, en erfaren frontsoldat fra Første Verdenskrig, viste her sine fortrinlige evner som forhandler. Han bad mig blive på kontoret. »Ny blyver $x$ forstander her, så fortæller $x$ dem: »die Direktion lehnt es ab! Wir haben königliches Staatsexamen mit ministeriellen Zensoren. Das geht nicht!« Tyskerne frafaldt deres krav og nøjedes med at beslaglxgge gymnastiksalen og beholdt deres "krudt « $i$ redskabsrummet. Indkvartering og anbringelse af vogne og feltkekkener voldte en del uro, men efter henstilling til den kommanderende officer om at de fremmede tropper udelukkende benyttede indgangen fra $\emptyset_{\text {stergade, }}$ samt at skildvagten skulle bortvise alle uvedkommende civilister fra seminariets park, lykkedes det at skabe tålelig ro og orden. En dag blev seminariet dog truet med udsmidning og lukning, en klasse havde for åbne vinduer sunget "Marseillaisen " under en appel $i$ parken. Det viste sig at være Henrik Wergelands "Frihed sejer i kampen forjætter « på den berømte melodi; men det gjorde ikke sagen bedre, og det blev nødvendigt at vælge sangene med lidt mere omhu - $\mathrm{i}$ hvert fald hvad angik melodier.

I løbet af juni måned, må der - formodentlig på baggrund af tyskernes indlemmelse af de $\mathrm{i}$ Versaillestraktaten ${ }^{40}$ nævnte områder Elsass-Lothringen og Eupen-Malmedy i Belgien - have bredt sig et ret sikker forventning i det tyske mindretal om påfølgende indlemmelse af Nordslesvig, hvormed den sidste rest af den forhadte fredstraktat fra Versailles 1919, $\$ 109-114$, ville være ssønderrevet $\alpha$. En af dagene omkring den 28. juni, den dato traktaten var blevet undertegnet, fortalte Frandsen mig, at man bl. a. i Vestergade var parat med middagsmad til ingen ringere end selve rigskansleren og hans følge. Der var i samme anledning ankommet ekstra politimandskab til Tonder, som opholdt sig i seminariets park og blev bespist i elevhjemmet. Noget over middag kom en dansk murer op gennem Vestergade. Han råbte i godt humør til nogle koner, der spejdede fra gadedørene: "Han er en møj precis mand. Nu er et øwer middaw, så I kan godt gå ind igen. Han kommer ett idaw! « Det gjorde han ikke, og han kom som bekendt aldrig.

Selv om der også $i$ visse danske kredse var oparbejdet en under- 
tiden ret lidenskabelig forventning til Nationalsocialismen og $"$ Det tredje Rige«, oplevede vi kun én udmeldelse på det grundlag. Den 4. juni indfandt en sønderjysk elev fra III klasse sig på mit kontor og bad om at måtte blive udmeldt med øjeblikkelig virkning. Han havde meldt sig som frivillig til den tyske "Vxrnemagt« og skulle på grund af et tidligere afgivet løfte uopholdeligt afrejse sydpå. Jeg foreholdt ham det ubetænksomme i således at afbryde den snart fuldendte læreruddannelse og beklagede dybt, at han kunne tæenke sig at gå $\mathrm{i}$ tysk krigstjeneste. Han syntes temmelig nedslået, men fastholdt sit ønske og afrejste samme dag.

Fire måneder senere, i oktober 1940, kom han pludselig tilbage, fortalte at han havde opholdt sig i en træningslejr $i$ Nordtyskland; men det hele havde været en frygtelig skuffelse, og han egnede sig ikke til at vxre soldat. Han angrede sin dumhed og bad indtrængende om at blive optaget igen, idet han ville afgive lefte om urokkelig loyalitet. Hans anmodning måtte naturligvis drøftes i larerrådet, og da hans faglige standpunkt havde været særdeles godt og hans adfærd i øvrigt upåklagelig, fik han med nogen betænkelighed lov til påny at indtræde i sin klasse, mod løfte om helt at afholde sig fra samkvem med fremmede soldater. Hans kammerater modtog ham, som der står $i$ en indberetning af $8 / 101940$, »uden sympati, men på henstilling også uden nogen art af demonstrativ uvilje«.

Han holdt sine lefter, og efter dimissionen i $1941 \mathrm{gav}$ jeg ham det indtrængende råd ikke at sege stilling $\mathrm{i}$ Sønderjylland, men hellere finde en lærerstilling i Nordjylland eller på Sjxlland. Mange år efter fik jeg et taknemligt brev fra ham; han var lærer ved en større københavnsk kommuneskole, glad ved sin gerning og frigjort for den splittelse, som grænselandet kan frembyde for usikre sjale. Han takkede for seminariets hjælpende hånd, da han havde været ved at styrte sig i ulykke.

I sommeren 1940 begyndte nedrivningen af en gammel staldbygning fra 1830erne og af det gamle alderdomshjems fløj ind mod seminariet. Den hermed indledte store udvidelse af seminariet var allerede planlagt under min forgænger. Nu blev den fremskyndet $\mathrm{i}$ forventning om voksende elevtal - og som et håndslag til Tønder fra Undervisningsministeriet. I løbet af godt et års tid var den gamle *Helligåndssal« fra Brorsons tid omdannet til en smuk læsesal og bibliotek. Seminariet fik en ny overlærerbolig, en pedellejlighed og en 
praktikklasse, som straks blev taget $\mathrm{i}$ brug. Vi havde nu 60 elever $\mathrm{i}$ I klasse, det højeste tal siden Genforeningen.

Som led i det åndelige beredskab, der i det gamle land førte til oprettelsen af Dansk Ungdomssamvirke og lignende organisationer, indbød vi, ofte i samarbejde med Tønder Statsskole, en række danske talere til offentlige møder. Her talte professor Hal Koch, ${ }^{41} \mathrm{dr}$. Therkel Mathiassen, ${ }^{42}$ forstander Lars Bækhøj, docent Jens Kruuse ${ }^{\mathbf{4 3}}$ og andre. Desuden lykkedes det at skaffe nogle meget værdifulde svenske gæstelærere til Tønder. Her er der især grund til at fremhæve rektor Petrus Enwall fra folkskoleseminariet i Falun, Dalarne.44 Med sin rige personlighed og sine fremragende lxrerevner lykkedes det ham at fængsle vore elever, som jeg aldrig har oplevet det for eller siden. De søgte ham til private samtaler, dannede på eget initiativ svenske studiekredse og flokkedes om ham, hvor han færdedes. Tidens frygtelige alvor, men også dens storhed og skæbnesvangre betydning kom gennem hans ord de unge danske elever nærmere ind på livet end før. Det var en dybt bevæget elevflok, der efter to rige uger tog afsked med denne ypperlige repræsentant for det frie Sverige.

Selv bragte rektor Enwall uforglemmelige indtryk med tilbage. Under hans ophold blev en stor engelsk bombemaskine skudt ned ude ved Jejsing. Mange af os blev kaldt til Tønder sygehus som bloddonorer, og i de følgende dage overvældedes de kvæstede englændere med blomster og gaver, indtil de $\mathrm{i}$ hast blev ført sydpå til en krigsfangelejr.

Fra et privat samvær på Schackenborg erindrer jeg grev Schacks ord til den svenske gæst: "Fortæl Deres landsmænd, der måske ikke alle forstår Danmarks holdning $\mathrm{i}$ disse år, at en dansk regering under disse forhold har en tommelskrue på, som hvert øjeblik kan spændes: truslen om med korteste varsel at flytte grænsen op til Kongeåen igen og udskrive dansk mandskab! Enhver dansk regering må $i$ alle sine handlinger tage nøje hensyn også til dette «. Grevens enkle og stærke billedsprog gjorde et dybt indtryk på rektor Enwall, han mindedes det endnu, da jeg i 1955 som gxstelektor besøgte seminariet i Falun.

\section{$\rightarrow$ Trange tider ....}

Midt i sommerferien, 11. juli 1942, ramtes Tønder by af en ulykke, 
der smerteligt greb ind i seminariets kreds. Nogle nedkastede bomber ødelagde en del bygninger $i$ den vestlige del af byen og dræbte flere mennesker, deriblandt lærer Poul Larsens hustru og fireårige datter. ${ }^{45}$ Selv blev han alvorligt kvæstet. Når Flensborg eller Hamborg blev bombet, lå Tønder vel ofte på allierede flyveres hjemvej.

Årsberetningen slutter med følgende ord. »Et nyt skoleår er nu begyndt, omtrent samtidig med krigens fjerde år. Alle spejder vi mod en lynsvanger synskreds med håb og mismod $i$ hjertet. Og så bøjer vi os mod vor gode daglige gerning, den der holder os oppe, og som vi skal passe med fasthed og selvbeherskelse. Det skulle vi lærere nok kunne gøre, vi der - $\mathrm{i}$ beskedenhed - måske tør sige med den sønderjyske historiker A. D. Jørgensens ord, at vi kan være lykkelige i bevidstheden om, at det forundes os at arbejde for Danmark. Med det håb, at landsmænd vil nævne også os fra skolestuen blandt dem, som $\mathrm{i}$ tunge tider aldrig mistvivlede om fædrelandets frelse ${ }^{46}$

Men nu var den "passive modstands periode $\mathrm{i}$ færd med at rinde ud også i Tønder, hvis ledende mænd i fuldt omfang støttede seminariets og Undervisningsministeriets ønske om længst muligt at bevare den danske lærerskole og øvelsesskolen, på den tid Tønders eneste danske børneskole.

I maj 1943 indtraf den første større sabotage i Tønder. 6 lokomotiver blev alvorligt beskadiget $\mathrm{i}$ remisen ved Tønder $\mathrm{H}$, den gamle marskbanegård. Utvivlsomt fra hjemmetysk side blev politiets opmærksomhed straks henledt på statsseminariet. Der blev foretaget afhøringer og visitationer, politiet bad endda forstanderen privat foretage afhøring af mistænkte elever, hvad jeg bestemt nægtede. En seminarieelev Johan Kyster blev arresteret, men kort efter løsladt igen, hvorefter han som medansvailig under fire ojne betroede sig til mig. Jeg foreslog ham hurtigst muligt at gå under jorden, da politiet tilsyneladende havde fået stærke beviser. Det ønskede han dog ikke og blev få dage efter arresteret påny. Kort efter løslod dommer Stegmann ${ }^{47}$ ham, "på grund af bevisets stilling «. Han fortsatte derefter på seminariet, indtil en stor arrestationsbølge - efter en ny

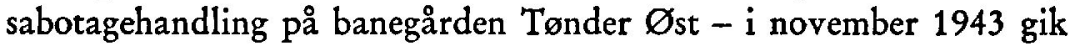
over Tonder. Det lykkedes Kyster at slippe bort i tide, mens 6 andre kammerater blev fanget. Vi bevarede forbindelsen med ham indtil befrielsen, hvor han vendte tilbage og fuldførte en uddannelse.

Det må ikke glemmes, at ca. en tredjedel af seminariets elever af 
pladshensyn lejede værelser hos hjemmetyske borgere. Dette pålagde naturligvis alle at udvise stor forsigtighed, $\mathrm{da}$ adskillige af disse borgere - skræmt af værnemagtens brutale trusler - følte sig forpligtet til at meddele politiet, senere Gestapo, enhver mistanke. Både Claus Eskildsen og jeg har $\mathrm{i}$ stilhed ordnet adskillige sådanne mellemværender mellem værtsfolk og lejere. Når disse forsog slog fejl, var der kun et at gøre, råde de mistænkte og truede elever til at gå under jorden og redde sig på den vis.

Om denne del af Tønder Statsseminariums historie under Besettelsen 1943-45 beretter de i Sønderjyske Årbøger 1968 meddelte dagbogsblade.

\section{NOTER}

1. Herluf Jensen, forstander for Silkeborg Seminarium 1933-58.

2. P. J. M. Winther, forstander for Silkeborg Seminarium 1890-1933.

3. Lars Bækhøj, forstander for Ollerup højskole 1914-37.

4. Emil Albeck, præst, forstander for Tonder Statsseminarium 1920-37.

5. Erik Appel, domæneforpagter på Ellehus 1926-51. Medlem af Folketinget (V) 1939-50.

6. Jørgen Jørgensen, undervisningsminister 1935-42. Indenrigsminister 1942 til 29/8 1943.

7. A. Barfod, departementschef i Undervisningsministeriet 1933-48.

8. Hans Novrup, amtsskolekonsulent Ảbenrå-Sonderborg amt 1937-59.

9. Claus Eskildsen, seminarielzrer i Tønder 1909-47. Forfatter bl. a. til Dansk Grænselære, 1936.

10. Aage Rahr, mag. art., seminarielærer i Tonder $1920-48$.

11. Thomas Roust, overlarer ved seminariets ovelsesskole 1937-41. Amtsskolekonsulent Haderslev 1941-62.

12. Erling Brahm, skoleinspektør ved seminariets øvelsesskole 1941-70.

13. Johs. Bonde, pedel ved Tonder Statsseminarium 1920-39.

14. Rasmus Frandsen, pedel ved Tonder Statsseminarium 1939-53.

15. Peter Atke, lerer ved Tønder Statsskole. Regnskabsfører ved seminariet $1920-42$.

16. Jørgen Utoft, seminarielæerer i Tønder 1933-49. Rektor for Haderslev Statsseminarium 1949--72.

17. Pastor Peperkorn, Fjolde, især fremtrædende $i$ de slesvig-holstenske nationalisters organisation 1932-33.

18. Tage Dam, dim. 1939. Stadsskoleinspektor i Nibe fra 1959.

19-20. Kronprins Frederik og Kronprinsesse Ingrid, Danmarks tronfølgerpar $1935-47$.

21. H. Jefsen Christensen, gårdejer i Høgsbro. Landstingsmand (V) 1920-53.

22. I. P. Nielsen, Dynt, redaktør. Medlem af Folketinget (S) 1920-43.

23. O. D. Schack, lensgreve, Schackenborg, Møgeltønder. Amtmand Tønder amt $1920-49$. 
24. Winston Churchill, britisk premierminister 1940-45.

25. Anthony Eden, britisk udenrigsminister 1935-38 og 1940-45.

26. Neville Chamberlain, britisk premierminister 1937-40.

27. Nicolai Svendsen, amtsskolekonsulent i Tønder amt 1920-46.

28. C. Elholm, skolekonsulent for de tyske skoler i Nordslesvig 1939-45.

29. Balthasar Petersen, provst i Tønder 1746-87. Åbnede i 1753 et "Lærerinstitut« og skænkede midler til oprettelse af Tønder Seminarium 1788.

30. Joakim Skovgaard, dansk maler, d. 1933.

31. A. Kühnel, forstander for »det dansk-slesvigske seminarium« $i$ Tønder 185664.

32. Cornelius Appel, lærer ved Tønder Seminarium 1851-64; senere frimenighedsprest i Rødding.

33. Lrs. H. Jepsen, borgmester i Tønder 1937-39.

34. Peter P. Rohde, lektor, historiker. Citat fra Midt $i$ en Ismetid, 1970, side 53.

35. Kaj Munk, præst og forfatter, d. 1944.

36. Jan Ballin, katolsk præst i Esbjerg 1936-43.

37. Otto $\vee$. Bismarck, Tysklands udenrigsminister og ministerpræsident 1862-90.

38. Torgny Segerstedt, svensk religionshistoriker og forfatter. 1917-45 redaktør af Göteborgs Handels- och Sjöfartstidningen. I marts 1937 afviste statsminister Th. Stauning $i$ en tale $i$ Lund tanken om et nordisk forsvarsforbund.

39. T. Martensen-Larsen, politimester i Tønder 1934-43.

40. F. C. Kaalund-Jergensen, statskonsulent for undervisningsministeriet 1930-48.

41. Hal Koch, professor, dr. theol. formand for Dansk Ungdoms-Samvirke $1940-46$.

42. Therkel Mathiassen, arkæolog, dr. phil. Overinspektør ved Nationalmuseet 1942-67.

43. Jens Kruuse, forfatter og litteraturkritiker.

44. Petrus Enwall, fil. dr. Sprogforsker og historiker, rektor for Falun folkskoleseminarium 1940-55.

45. Poul Larsen, lærer ved Tønder Statsseminariums øvelsesskole 1935-66.

46. A. D. Jørgensen, 1840-97. Historiker, rigsarkivar.

47. H. H. Stegmann, dommer i Tønder købstad m.v. 1937-54. 